\title{
In vitro immune toxicity of polybrominated diphenyl ethers on murine peritoneal macrophages: Apoptosis and immune cell dysfunction
}

\author{
Qi-Yan Lv, Bin Wan*, Liang-Hong Guo*, Lixia Zhao, Yu Yang \\ State Key Laboratory of Environmental Chemistry and Ecotoxicology, Research Center for Eco-Environmental Sciences, Chinese Academy of Sciences, Beijing 10085, China
}

\section{H I G H L I G H T S}

- PBDEs induced macrophage apoptosis.

- ROS levels were increased and GSH was depleted in PBDE-exposed macrophages.

- NAC could only partially attenuate the cytotoxicity of PBDEs.

- Both intrinsic and extrinsic apoptotic pathways were activated by PBDEs.

- Macrophage accessory cell function was inhibited by non-cytotoxic levels of PBDEs.

\section{A R T I C L E I N F O}

\section{Article history:}

Received 21 April 2014

Received in revised form 22 July 2014

Accepted 7 August 2014

Available online 28 October 2014

Handling Editor: A. Gies

\section{Keywords:}

PBDEs

Macrophage functions

Apoptosis

Immunotoxicity

In vitro

\begin{abstract}
A B S T R A C T
Polybrominated diphenyl ethers (PBDEs) are widely used as flame retardants and are often detected in the environment, wildlife, and humans, presenting potential threats to ecosystem and human health. PBDEs can cause neurotoxicity, hepatotoxicity, and endocrine disruption. However, data on PBDE immunotoxicity are limited, and the toxicity mechanisms remain largely unknown. Both immune cell death and dysfunction can modulate the responses of the immune system. This study examined the toxic effects of $2,2^{\prime}$, 4,4'-tetrabromodiphenyl ether (BDE-47) and decabromodiphenyl ether (BDE-209) on the immune system by using peritoneal macrophages as the model. The macrophages were exposed to PBDEs, and cell death was determined through flow cytometry and immunochemical blot. The results showed that after $24 \mathrm{~h}$ of exposure, BDE-47 $(>5 \mu \mathrm{M})$ and BDE-209 $(>20 \mu \mathrm{M})$ induced cell apoptosis, increased intracellular reactive oxygen species (ROS) formation and depleted glutathione. BDE-47 was more potent than BDE-209; the cytotoxic concentrations for BDE-47 and BDE-209 were determined to be $5 \mu \mathrm{M}$ and $20 \mu \mathrm{M}$, respectively, during $24 \mathrm{~h}$ of exposure. However, pretreatment with $\mathrm{N}$-acetyl-L-cysteine (ROS scavenger) partially reversed the cytotoxic effects. Further gene expression analyses on Caspase-3,-8,-9, TNFR1, and Bax revealed that both intrinsic and extrinsic apoptotic pathways were activated. More importantly, non-cytotoxic concentrations BDE-47 $(<2 \mu \mathrm{M})$ and BDE-209 $(<10 \mu \mathrm{M})$ could impair macrophage accessory cell function in a concentration-dependent manner, but no effects were observed on phagocytic responses. These revealed effects of PBDEs on macrophages may shed light on the toxicity mechanisms of PBDEs and suggest the necessity of evaluating cellular functionality during the risk assessment of PBDE immunotoxicity.
\end{abstract}

(c) 2014 Elsevier Ltd. All rights reserved.

\section{Introduction}

Polybrominated diphenyl ethers (PBDEs), a group of highly hydrophobic organic chemicals, have been widely used as flame retardants since the 1970 s in textiles, electronics, motor vehicles and polyurethane foam, among other products (Stapleton et al.,

\footnotetext{
* Corresponding authors at: State Key Laboratory of Environmental Chemistry and Ecotoxicology, Research Center for Eco-environmental Sciences, The Chinese Academy of Science, 18 Shuangqing Road, P.O. Box 2871, Beijing 100085, China. Tel.: +86106284 9338; fax: +861062849685.

E-mail addresses: binwan@rcees.ac.cn (B. Wan), LHGuo@rcees.ac.cn (L.-H. Guo).
}

2011). The presence of PBDEs has been detected in various environmental compartments and biological samples (Kim et al., 2012; Zhang et al., 2012), even after their phase-out (Dodson et al., 2012), due to their persistent nature. PBDEs have been reportedly found in indoor dust, carpet, human serum, hair, and breast milk, even in younger children (Rose et al., 2010). The mean estimated daily intake of PBDEs by breast-fed infants ranged from 9.9 to $335.9 \mathrm{ng} \mathrm{kg}^{-1}$ body weight (bw) per day in Shenzhen, China (Zhang et al., 2012).

PBDEs and their metabolites were most often shown to cause adverse effects on several biological systems, including the central 
nervous system (Dingemans et al., 2011), the liver, reproduction and development (Li et al., 2012) and the endocrine system (Chen et al., 2012; Ren and Guo, 2012; Li et al., 2013; Ren and Guo, 2013). Although there is limited information on the immunotoxicity of PBDEs, recent animal investigations indicate suppressive effects of PBDEs on the immune system. For example, thymic atrophy, splenic depletion and lymphoid depletion were found to significantly correlate with increased PBDE levels in Harbor porpoises from the North and Baltic Seas, along with continuous stimulation of anti-inflammatory cytokines expression, such as IL-10 (Beineke et al., 2005, 2007). Juvenile subyearling Chinook salmon (Oncorhynchus tshawytscha), fed with a diet containing various PBDE congeners (BDE-47, BDE-99, BDE-100, BDE-153, and BDE-154) for $40 \mathrm{~d}$, were more susceptible to infectious diseases, with reduced inflammatory responses (Arkoosh et al., 2010). Gender-dependent immunosuppressive effects of BDE-47 were found in Oryzias melastigma (Ye et al., 2011). Rats exposed to large doses of BDE-209 showed a suppression of immune function, lymphocyte proliferation and antibody production (Liu et al., 2012). Perinatal exposure to the brominated diphenyl ether (BDE) mixture DE-71 resulted in hepatic and thyroid changes in rats, associated with altered splenic lymphocyte populations (Bondy et al., 2013). In vitro, PBDEs suppressed the phagocytosis of macrophage cells (Frouin et al., 2010) and the release of pro-inflammatory cytokines (Hennigar et al., 2012).

While the results of the above-mentioned studies may shed some light on the immunotoxicity of PBDEs, the effects of PBDEs on immune cells were not evaluated comprehensively, and the toxicity mechanisms for immunosuppression remain largely unknown. In this study, we hypothesized that PBDE exposure may compromise immune system function by inducing immune cell apoptosis and modulating immune cell functions, which may be predictive of PBDE immunotoxicity. This hypothesis is consistent with the findings of Li et al. (2001), Pallardy et al. (1999), and Rodenburg et al. (2000), which showed that cell death through apoptosis or necrosis might cause serious adverse effects, such as immunosuppression, or lead to an altered immune response. More specifically, macrophages play a crucial role in both innate immunity and acquired immunity, and because of their phagocytotic activity and ubiquitous presence throughout the body, it is also important to assess the effect PBDEs may have on macrophage function as accessory cells to T-lymphocyte activation/ proliferation.

In this study, we exposed primary murine peritoneal macrophages to two PBDE congeners, 2,2',4,4'-tetrabromodiphenyl ether (BDE-47) and decabromodiphenyl ether (BDE-209), and examined the effects of apoptosis and altered macrophage functions in promoting lymphocyte proliferation and phagocytosis. BDE-47 and BDE-209 were selected because of their high production rates and usage in history, the highest detection percentages in the environment and their potential toxicity (Wang et al., 2011; Zhang et al., 2012). In addition, reactive oxygen species (ROS) have been suggested to cause reduced pro-inflammatory responses, suppressed cell phagocytosis, mitochondrial dysfunction and cell apoptosis (Reistad and Mariussen, 2005; Frouin et al., 2010; Yan et al., 2011). Therefore, we examined intracellular redox substances and the expression of apoptosis-related genes.

\section{Materials and methods}

\subsection{Reagents}

2,2',4,4'-Tetrabromodiphenyl ether (BDE-47, 100\% purity, CAS: 5436-43-1) was purchased from AccuStandard Inc. (New Haven, CT, USA). Decabromodiphenyl ether (BDE-209, 99\% purity, CAS:
1163-19-5) was obtained from Dr. Ehrenstorfer GmbH (Augsburg, Germany). Concanavalin A (Con A) was purchased from Sigma Inc. (St. Louis, MO, USA). N-acetyl-L-cysteine was obtained from AMRESCO (Solon, OH, USA). Staurosporine was obtained from Beyotime Institute of Biotechnology (Jiangsu, China). All stock solutions were dissolved in DMSO. Anti- $\beta$-actin and anti-Caspase3 antibodies were obtained from Cell Signaling Technology, Inc. (Danvers, MA, USA). All cell culture media and ingredients were from GIBCO Inc. (Invitrogen Life Technology, CA, USA).

\subsection{Animal}

Female Kunming mice were obtained from the Department of Laboratory Animal Science (Peking University, Beijing, China) and bred and housed under pathogen-free conditions in the animal care facility at Peking University (Beijing, China). Mice aged 6-8 weeks were used for cell preparations.

\subsection{Cell preparations and PBDE exposure}

Mouse peritoneal elicited macrophages and splenic $\mathrm{CD} 4^{+} \mathrm{T}$ cells were prepared exactly according to the method described by Wan et al. (2006). The resulting macrophage and T cell purities were all $>95 \%$, as determined by CD11b and CD4 staining analyses. For cell viability and ROS/GSH analyses, the macrophages were exposed to BDE-47 $(0-10 \mu \mathrm{M})$ or BDE-209 $(0-50 \mu \mathrm{M})$ for $24 \mathrm{~h}$, and $\mathrm{H}_{2} \mathrm{O}_{2}$ $(100 \mu \mathrm{M}, 2 \mathrm{~h})$ was used as a positive control. For western blot analyses, macrophages were exposed to BDE-47 (5 $\mu \mathrm{M})$ or BDE-209 $(50 \mu \mathrm{M})$ for $2,4,6,8,12$, and $24 \mathrm{~h}$ and Staurosporine (STSP, $1 \mu \mathrm{M}, 2 \mathrm{~h}$ ) was used as a positive control. The obtained T cells, after washing once with RPMI-1640 and adjusting the concentration of the cells to $1 \times 10^{6}$ cells $\mathrm{mL}^{-1}$ in cRPMI-1640, were used for the T lymphocyte proliferation assay. Fresh cells from new living animals were purified each time the assays were repeated; three individual experiments were performed $(n=3)$.

\subsection{Cell viability analysis}

Macrophage apoptosis and necrosis was detected, using flow cytometry, according to the protocol provided with the AnnexinV-fluorescein (Annexin-V-FITC) Apoptosis Detection Kit (Bestbio. Co. Ltd. Shanghai, China), and the analysis was performed in triplicate. The macrophage cells $\left(1 \times 10^{6}\right.$ cells $\left.\mathrm{mL}^{-1}\right)$ were exposed to BDE-47 or BDE-209 and then harvested and washed once with cold PBS and re-suspended in $1 \times$ binding buffer. A $400-\mu \mathrm{L}$ aliquot of the cell suspension was stained with $5 \mu \mathrm{L}$ of Annexin-V-FITC and $10 \mu \mathrm{L}$ of PI, protected from light. We then analyzed cells using the flow cytometry LSR II (BD Biosciences) by counting 10000 events. In quadrant analysis, the percentage of apoptotic (Annexin-V-FITC $/ \mathrm{PI}^{-}$) and necrotic (Annexin- $\mathrm{V}^{+} / \mathrm{PI}^{+}$) cells was determined using WinMDI software (version 2.9; the Scripps Institute, Flow Cytometry Core Facility, La Jolla, CA, USA). In addition, the viability of macrophages, with or without $\mathrm{N}$-acetyl-L-cysteine (ROS scavenger, NAC, $5 \mathrm{mM}, 24 \mathrm{~h}$ ) pretreatment, was measured using WST- 1 assay (Roche Applied Science, Bavaria, Germany) by reading absorbance at $490 \mathrm{~nm}(690 \mathrm{~nm}$ for background subtraction). Cells exposed to $1 \%$ DMSO (v/v) were set as vehicle control (VC). Fresh cells from new living animals were purified each time the assays were repeated; three individual experiments were performed $(n=3)$.

\subsection{Measurement of reactive oxygen species (ROS) and total glutathione level}

The production of ROS in macrophages was determined by measuring the fluorescence intensity of dichlorofluorescein (DCF), 
which is the oxidized form of the non-fluorescent dichlorofluorescein diacetate (DCFDA). The mouse peritoneal macrophages were pooled and plated onto a 24-well flat-bottom plate and incubated in HBSS containing $100 \mu \mathrm{M}$ DCFDA or an equal amount of HBSS (blank control) for $30 \mathrm{~min}$. At the end of the incubation, the cells were washed and immediately exposed to HBSS containing various concentrations of PBDEs for $24 \mathrm{~h}$. The fluorescence intensity was measured using a Varioskan Flash microplate reader (Thermo, MA, USA) at excitation $=488 \mathrm{~nm}$ and emission $=525 \mathrm{~nm}$. To rule out the possibility that BDE-47 and BDE-209 may interfere with the fluorescence of DCF probes, we compared the fluorescence intensities before and after the addition of PBDEs and did not observe significant differences (see supporting information, Fig. S1).

The total intracellular Glutathione (GSH) level was measured in PBDE-exposed macrophages using a Total Glutathione Quantification Kit (Dojindo Molecular Technologies, Kumamoto, Japan), according to the manufacturer's instructions. In brief, macrophages $\left(3 \times 10^{5}\right.$ cell $\left.\mathrm{mL}^{-1}\right)$ were seeded and exposed to BDE-47 or BDE209. After $24 \mathrm{~h}$ of exposure, cells were collected and divided into two parts for GSH assays and BCA protein assays, respectively. For GSH assays, cells were re-suspended with $10 \mathrm{mM} \mathrm{HCl}$, which was followed by freezing and thawing using liquid nitrogen and the addition of $20 \mu \mathrm{L}$ sulfosalicylic acid solution (5\%). After centrifugation, $20 \mu \mathrm{L}$ supernatants were divided into aliquots and reacted with a reaction mixture containing 5,5'-dithiobis(2-nitrobenzoic acid) (DTNB), NADPH, and glutathione reductase in a 96well plate for $10 \mathrm{~min}$, at $37^{\circ} \mathrm{C}$. The absorbance was measured at $405 \mathrm{~nm}$ using a microplate reader (Varioskan Flash, Thermo, MA, USA), and the data were processed using a kinetic method. The corresponding protein concentration of each sample was measured using a BCA Protein Assay Kit (Beyotime Institute of Biotechnology, Jiangsu, China) to normalize the quantity of cells in each sample, according to manufacturer's instructions. The measurement of ROS and GSH was repeated at least three times, with fresh cells isolated and used in each individual experiment. The data were collected from three individual experiments and expressed as fold change against control.

\subsection{Western blot}

After exposure, macrophages were washed twice with ice-cold PBS, and total cellular protein was isolated by lysing the cells with RIPA buffer containing a protease inhibitor mixture. The concentration of each protein sample was measured with a BCA Protein Assay Kit (Beyotime Institute of Biotechnology, Jiangsu, China) according to the manufacturer's instructions. Then, $10 \mu \mathrm{g}$ of protein was separated by SDS-PAGE and transferred to a PVDF membrane. The membrane was incubated with anti-Caspase- 3 primary antibody overnight at $4{ }^{\circ} \mathrm{C}$, and the primary antigen-antibody complex was detected by incubating the blot with a horseradish peroxidase-conjugated secondary antibody at room temperature for $1 \mathrm{~h}$. The membrane was further developed with the ECL Plus Western blotting detection system (Millipore Corporation, Billerica, MA, USA). $\beta$-Actin was used as an internal reference for protein loading control. The relative abundance of active Caspase-3 against total Caspase- 3 was measured by using Gel pro analyzer software (Version 4.0, Media Cybernetics, Inc., Bethesda, MD, USA). In the case of NAC pre-treatment, cells were pre-exposed to NAC for $2 \mathrm{~h}$ and then co-incubated with BDE-47 or BDE-209 for another $24 \mathrm{~h}$, which was followed by Western blot analysis. Three individual experiments were performed.

\subsection{Real-time reverse-transcriptase PCR analysis}

Total RNA was extracted from cells using Trizol reagent according to the manufacturer's instruction (Invitrogen Inc., CA,
USA). The quality and quantity of the purified total RNA were assessed using a Nanodrop 1000 spectrophotometer (Thermo Scientific Inc., Waltham, MA, USA). Total RNA was converted to first-strand cDNA with reverse transcription using oligo $(\mathrm{dT})_{18}$ primer with a RevertAid First Strand cDNA Synthesis Kit (Fermentas China Co. Ltd, Shenzhen, China). The GoTaq ${ }^{\circledR}$ qPCR Master Mix (Promega, Madison, WI, USA) was used to perform Q-PCR analysis according to the manufacturer's protocol. The assay was performed in triplicate on an Mx3005P real-time QPCR system (Stratagene, La Jolla, CA, USA). The primers we used are listed in Table 1 . The PCR reaction was performed as follows: 2 min at $95^{\circ} \mathrm{C}$ followed by $15 \mathrm{~s}$ at $95^{\circ} \mathrm{C}, 1 \mathrm{~min}$ at $60^{\circ} \mathrm{C}$ for 40 cycles. The cycle threshold $(\mathrm{Ct})$ for each sample was generated by the MxPro software (Stratagene, La Jolla, CA, USA). The Ct values for each sample correspond to the point at which the fluorescence crosses the threshold. Afterwards, melting curve analysis and gel electrophoresis was performed to assess the specificity of PCR amplification reactions. The housekeeping gene glyceraldehyde-3-phosphate dehydrogenase (GAPDH) was used as an endogenous control. The formulation used for calculating the ratio of gene expression between control and treatment groups was described previously (Pfaffl et al., 2002).

\subsection{Phagocytosis assay of mouse peritoneal macrophages}

After PBDE exposure, macrophage cells were washed twice with pre-warmed PBS and then incubated with Latex beads $(\varnothing=1 \mu \mathrm{m})$ (ex: $575 \mathrm{~nm}$, em: $610 \mathrm{~nm}$ ) (Sigma, St. Louis, MO, USA) at $37^{\circ} \mathrm{C}$ in $5 \% \mathrm{CO}_{2} / 95 \%$ air, and $95 \%$ humidity for $2 \mathrm{~h}$. The adherent cells were harvested by trypsinisation and then washed once with cold PBS. Cell suspensions in PBS were analyzed immediately with BD LSR II flow cytometry. The percentage of cells engulfing latex beads (phagocytosis ratio) and phagocytic efficiency (mean fluorescence intensity of phagocytic cells, which denotes average number of latex beads engulfed by each cell) were determined using WinMDI software (version 2.9). Three biological replications were performed with fresh macrophages isolated and used in each experiment.

\subsection{T-lymphocyte proliferation assay}

We used a T-lymphocyte proliferation assay to estimate the macrophage function as accessory cells. The exposure follows the model described by Krocova et al. (2000): elicited peritoneal macrophages were cultured in 96-well microtiter plates (Corning Inc., Corning, NY, USA), allowed to adhere for $4 \mathrm{~h}$, and then exposed to cRPMI-1640 containing BDE-47 $(0,0.5,1$, and $2 \mu \mathrm{M})$ or BDE$209(0,1,5$, and $10 \mu \mathrm{M})$ or equal amount of media. After $24 \mathrm{~h}$ of incubation, the cells were washed, and the purified $\mathrm{CD} 4^{+} \mathrm{T}$ cell suspension $\left(1 \times 10^{6}\right.$ cells $\left.\mathrm{mL}^{-1}\right)$, with or without Con $\mathrm{A}\left(5 \mu \mathrm{g} \mathrm{mL}^{-1}\right)$, was then added to each well containing treated adherent macrophages. The plate was incubated at $37{ }^{\circ} \mathrm{C}, 5 \% \mathrm{CO}_{2} / 95 \%$ air, and $95 \%$ humidity for $72 \mathrm{~h}$. T-cell proliferation was then determined by Alamar Blue assay by reading the fluorescence at excitation $=530 \mathrm{~nm}$, and emission $=590 \mathrm{~nm}$ on a Thermo Varioskan Flash microplate reader (Thermo, MA, USA). The proliferation assay was repeated three times with fresh cells isolated and used in each individual experiment.

\subsection{Statistics}

The data are expressed as the means $\pm \mathrm{SD}$, and Student's $t$-test was used to evaluate the differences between groups, with the significance level set at ${ }^{*} p<0.05$. 
Table 1

Quantitative real-time PCR measurement of apoptotic gene expressions in macrophages upon $5 \mu \mathrm{M}$ BDE-47 exposure.

\begin{tabular}{|c|c|c|c|}
\hline Gene name & Gen Bank Acc. No. & Primer sequence (from $5^{\prime}$-to- $3^{\prime}$ ) & Fold change $(\mathrm{T} / \mathrm{C})$ \\
\hline Caspase-3 & NM_001284409.1 & $\begin{array}{l}\text { F: GGGCCTGAAATACCAAGTCA } \\
\text { R: TCCCATAAATGACCCCTTCA }\end{array}$ & 2.4 \\
\hline Caspase- 8 & NM_001277926.1 & $\begin{array}{l}\text { F: GCTTTTCCACATCAGTCGGT } \\
\text { R: GCATGACCCTGTAGGGAGA }\end{array}$ & 2.1 \\
\hline Caspase- 9 & NM_001277932.1 & $\begin{array}{l}\text { F: GACAAGGGTGTCGTCTATGG } \\
\text { R: AGGCACTCCTTTCTGGAAGT }\end{array}$ & 3.1 \\
\hline Bax & NM_007527.3 & $\begin{array}{l}\text { F: CGGCGAATTGGAGATGAACTG } \\
\text { R: GCAAAGTAGAAGAGGGCAACC }\end{array}$ & 2.7 \\
\hline TNFR1 & NM_011609.4 & $\begin{array}{l}\text { F: GACCGGGAGAAGAGGGATAG } \\
\text { R: GTTCCTTTGTGGCACTTGGT }\end{array}$ & 1.6 \\
\hline GAPDH $^{\mathrm{a}}$ & NM_008084.2 & $\begin{array}{l}\text { F: TGATGACATCAAGAAGGTGGTGAAG } \\
\text { R: TCCTTGGAGGCCATGTAGGCCAT }\end{array}$ & - \\
\hline
\end{tabular}

$\mathrm{F}$, forward primer; $\mathrm{R}$, reverse primer

a This gene was used as reference gene for the normalization of target gene expression.

\section{Results}

\subsection{Cell viability and apoptosis}

Typical quadrant analyses on 10000 cells are shown in Fig. 1A and B. The cell apoptosis rate in control, 5, and $10 \mu \mathrm{M} \mathrm{BDE}-47$ was $4.5 \%, 23.8 \%$, and $27.2 \%$, respectively (Fig. 1C). The total viability loses (apoptosis and necrosis) were $41.8 \%$ and $36.1 \%$ for the 5 and $10 \mu \mathrm{M}$ groups, respectively. No significant changes were found in the percentages of apoptosis and necrosis in lower concentrations $(<5 \mu \mathrm{M})$ (Fig. 1C). To a lesser extent, 20 and $50 \mu \mathrm{M}$ BDE-209 caused approximately $6.1 \%$ and $9.5 \%$ cell apoptosis and $13.5 \%$ and $21.1 \%$ total viability loss, respectively (Fig. 1D). In addition, analyses on Caspase- 3 expression through Western blotting showed a timedependent activation of Caspase-3 (19/17 kDa), in which the ratio peaks at $8 \mathrm{~h}$ and then the activation fades off at $24 \mathrm{~h}$ after $5 \mu \mathrm{M}$ BDE-47 exposure (Fig. 2A). Similarly, BDE-209-induced activation of Caspase-3 peaks at $12 \mathrm{~h}$ (Fig. 2B). These results suggest that PBDE exposure induces macrophage apoptosis in a concentrationand time-dependent manner, and BDE-47 is more toxic than BDE209.

\subsection{Intracellular ROS and GSH}

In this study, a concentration-dependent increase in the ROS level was detected in BDE-47 and BDE-209 exposed macrophages. Specifically, $5 \mu \mathrm{M}$ and $10 \mu \mathrm{M}$ BDE-47 increased ROS level by 1.3 and 1.8 -fold $(p<0.05)$, respectively; meanwhile, $10 \mu \mathrm{M}$ BDE-47 significantly $(p<0.05)$ decreased GSH levels to 36 percent of control (Fig. 3A). Similarly, $10 \mu \mathrm{M}, 20 \mu \mathrm{M}$ and $50 \mu \mathrm{M}$ BDE-209 significantly $(p<0.05)$ induced ROS production by $1.2,1.5$, and 1.7 -fold, respectively, and $50 \mu \mathrm{M}$ BDE-209 significantly $(p<0.05)$ reduced the GSH level to 60 percent of control (Fig. 3B). The results showed that PBDEs induced ROS production and GSH depletion in macrophages and that the increase in the ROS level was in accordance with the reduction of GSH level.

\subsection{Apoptotic gene expression and pathways}

To investigate the role of ROS in macrophage apoptosis, we pretreated cells with $\mathrm{N}$-acetyl-L-cysteine (ROS scavenger, NAC) and then exposed those cells to PBDE. A concentration-dependent activation and cleavage of procaspase- 3 protein was observed in macrophages with 2 and $5 \mu \mathrm{M}$ BDE-47 exposure; however, pretreatment with NAC did not prevent the activation of procaspase- 3 in these two groups, manifested as the continuous presence of $17 / 19 \mathrm{kDa}$ bands (Fig. 4A). In addition, pretreatment of macrophages with $5 \mathrm{mM}$ NAC only partially alleviated the cytotoxicity of BDE-47. The cell viability increased from 0.56 to 0.65 ( $5 \mu \mathrm{M}$ group) and from 0.21 to 0.31 (10 $\mu \mathrm{M}$ group); however, the overall viabilities remained lower than that of the control (Fig. 4B), suggesting that there are other pathways involved in BDE-47-induced apoptosis, except for the mitochondrial pathway.

We then performed quantitative real-time PCR to study the expression of various apoptosis-related genes involved in intrinsic and extrinsic pathways. As shown in Table 1, the executioner, Caspase-3, was up-regulated by 2.4 -fold, which is consistent with the results obtained through cellular and immunochemical analyses as mentioned above. It is not surprising that the two intrinsic pathway-associated genes, Caspase- 9 and Bax, were induced by 3.1 and 2.7-fold, respectively, further confirming the involvement of the mitochondrial pathway. In addition, Caspase- 8 and TNFR1 were also induced by 2.1 and 1.6-fold, respectively, indicating at least a partial role of the extrinsic pathway in PBDE-induced macrophage apoptosis. Taken together, these data suggest that both intrinsic and extrinsic apoptosis pathways were involved in PBDE-induced cytotoxicity and that BDE-47-induced macrophage apoptosis could only be partially alleviated by NAC pretreatment.

\subsection{Phagocytic function of macrophages}

Flow cytometry analyses revealed that the phagocytosis efficiency (i.e., fluorescence intensity (a.u.)) decreased significantly from 142.8 (control) to 89.0 (5 $\mu \mathrm{M}$ BDE-47) (Fig. 5A and C), indicating inhibited phagocytic efficiency of macrophages upon exposure. However, the phagocytosis ratio (i.e., phagocytic cell percentage of total cells) remained unchanged within the testing concentrations (Fig. 5A). No effects were found on these two parameters with BDE209 exposure (Fig. 5B). Cells cultured at a low temperature were used as a positive control (ice group), and significant decreases in both parameters were observed (Fig. 5). The results indicate that BDE-47, only at toxic concentrations, impaired the phagocytic function of macrophages by reducing the number of engulfed beads in each individual cell, and at non-cytotoxic concentrations, neither BDE-47 nor BDE-209 inhibited phagocytic function of macrophages.

\subsection{Accessory cell function of macrophages}

A T lymphoproliferation assay was performed to evaluate the accessory cell function of macrophages. We purified peritoneal macrophages and $\mathrm{CD} 4^{+} \mathrm{T}$ cells and pre-exposed the macrophages to PBDEs for $24 \mathrm{~h}$, which was followed by replacing the exposure medium with fresh medium containing $\mathrm{CD} 4^{+} \mathrm{T}$ cells. As shown in 

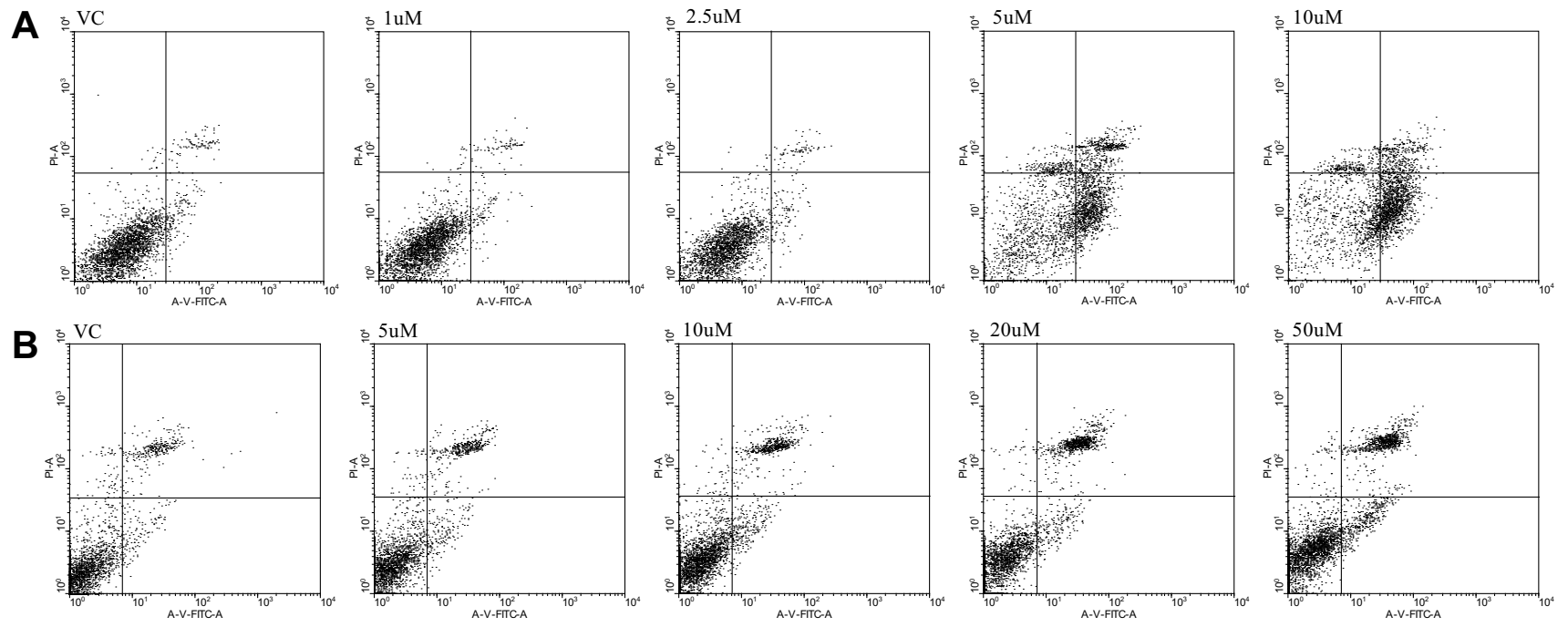

C
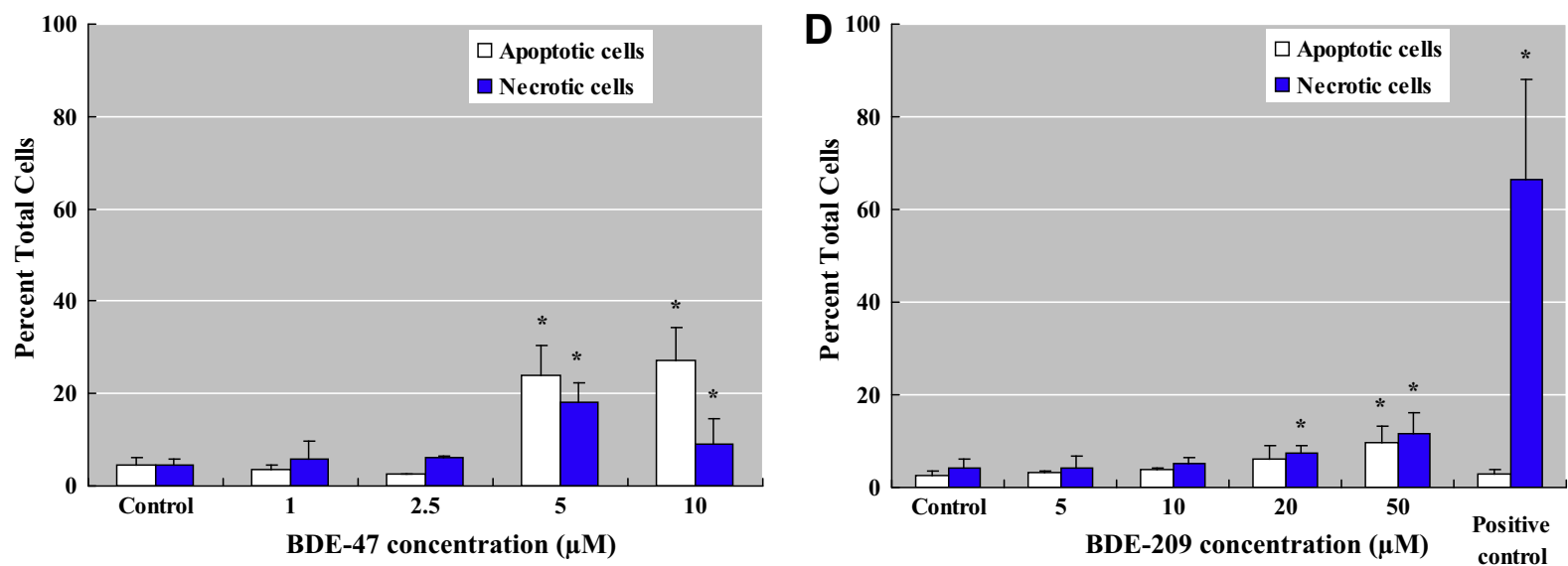

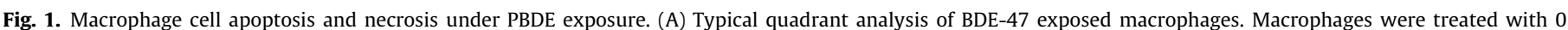

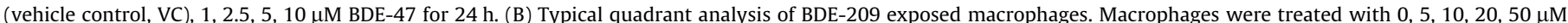

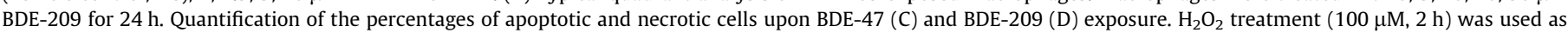
positive control. Data are the means of three individual experiments. Error bars represent SD. Asterisk indicates significant difference from control at level ${ }^{*}<<0.05$.

Fig. 6C, $2 \mu \mathrm{M}$ BDE-47 significantly inhibited the functionality of macrophages, as shown by decreased T-cell proliferation and decreased cell clump size under the induction of Con A. Quantitatively, BDE-47 significantly $(p<0.05)$ inhibited T-cell proliferation in a concentration-dependent manner, with the optical density ratio (treatment/control, $\mathrm{T} / \mathrm{C}$ ) decreasing from 1 (control) to 0.79 , 0.74 , and 0.65 upon $0.5,1$, and $2 \mu \mathrm{M}$ BDE-47 exposure, respectively (Fig. 6A). In addition, we set up controls in which no Con A was added to provide information on the direct toxicity of BDE-47 to cells. The results showed that, at the testing concentrations, BDE47 treatment did not cause significant loss of cell viability (Fig. 6A, solid bars). Similar tendencies were observed for BDE209 exposed cells, where $10 \mu \mathrm{M}$ BDE-209 exposure resulted in a decrease in the optical density ratio from 1 (control) to 0.76 (Fig. 6B). It is worth noting that the highest concentrations of PBDEs, $2 \mu \mathrm{M}$ for BDE-47 and $10 \mu \mathrm{M}$ for BDE-209, are non-cytotoxic to macrophages as measured by flow cytometry, indicating that PBDE might adversely affect macrophage functions without causing direct cell death.

\section{Discussion}

Lines of evidence showed that chemical-induced immune cell death or dysfunction could cause significant adverse effects to the immune system (Pallardy et al., 1999; Li et al., 2001). Recently, experimental data using animal models strongly suggested the occurrence of PBDE immunotoxicity, manifested as altered splenic lymphocyte populations, increased susceptibility to infections, and the release of pro-inflammatory cytokines (Zhong et al., 2011; Pellacani et al., 2012; Bondy et al., 2013). However, the data on PBDE immunotoxicity are still limited, and the mechanism(s) remains largely unclear. Macrophages play a critical role in both innate and adaptive immunities, acting as the scavengers as well as the regulatory cells. Macrophage deficiency or dysfunction may result in increased susceptibility to diseases and infections, altered immune response and abnormal immune cell maturation. In this study, primary murine peritoneal macrophages were employed for toxicological studies because they closely resemble the tissue environment. It has been reported that PBDE concentrations are high in the environment and continuously increase with a doubling time of 5 years in human body, even after its phase-out (Hites, 2004). In marine mammals and human serum, the PBDE concentration reaches as high as $1000 \mathrm{ng} \mathrm{g}^{-1}$ lipid and $334.18 \mathrm{ng} \mathrm{g}^{-1}$ lipid, respectively (Ni et al., 2013). By considering PBDEs' high bioaccumulation capability and potentially high occupational exposure scenarios, such as E-waste workers in Taizhou, China (Ni et al., 2013), we set three groups of concentrations to represent low (BDE-47, $1 \mu \mathrm{M}$; BDE-209, $5 \mu \mathrm{M}$ ), medium (BDE-47, $2 \mu \mathrm{M}$; BDE-209, $10 \mu \mathrm{M}$ ), and high (BDE-47, 5 and $10 \mu \mathrm{M}$; 

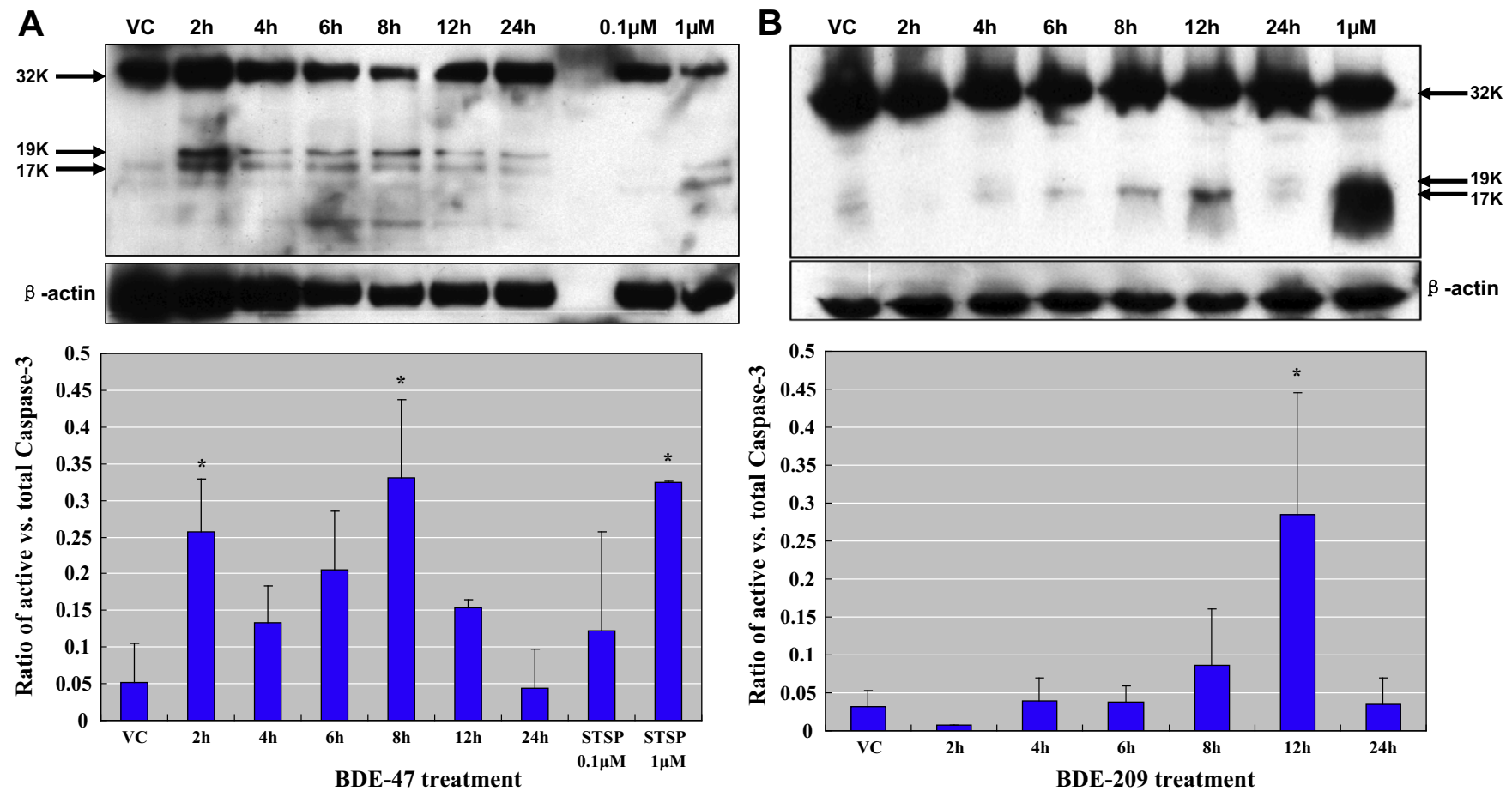

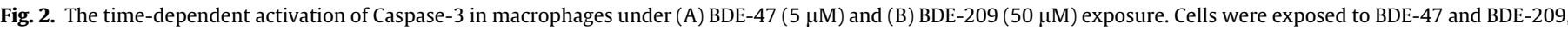

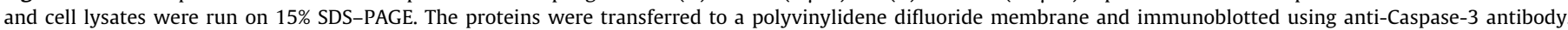

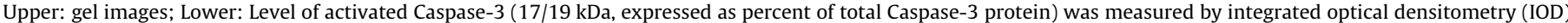

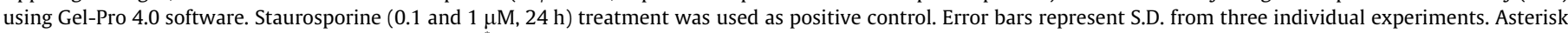
indicates significant difference from control at level ${ }^{*} p<0.05$.
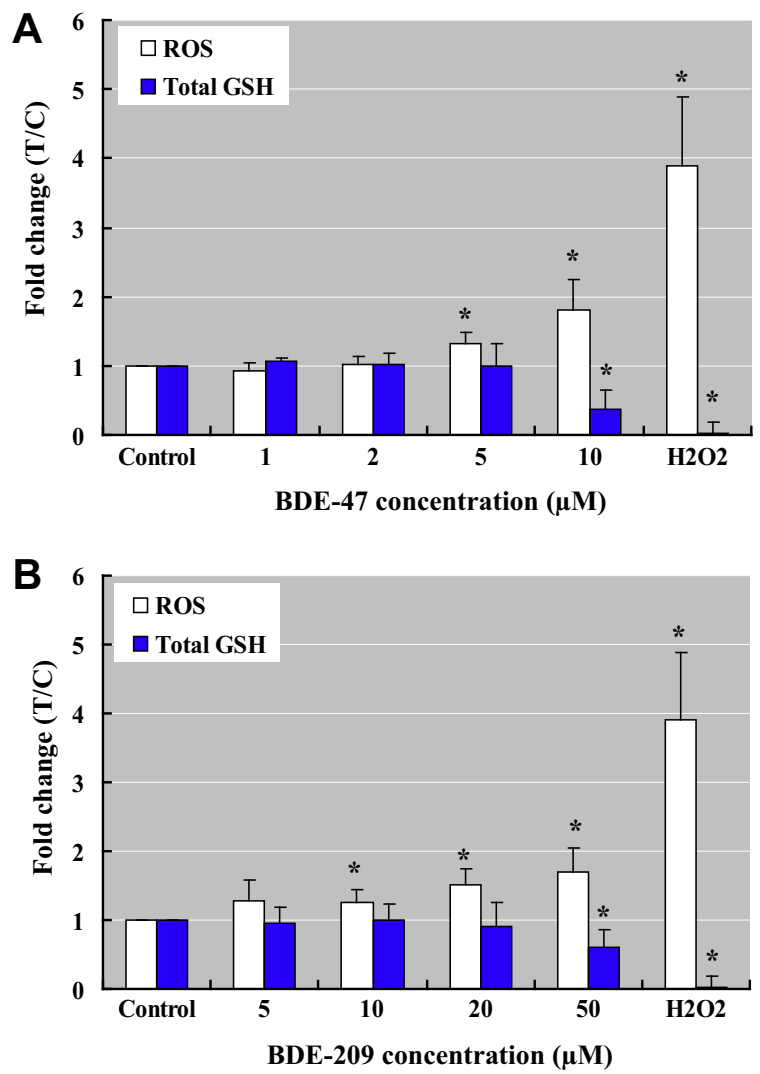

Fig. 3. Reactive oxygen species (ROS) and glutathione (GSH) levels in peritoneal macrophages under BDE-47 (A) and BDE-209 (B) exposure. Data are the means of three individual experiments. Error bars represent S.D. Asterisk indicates significant difference from control at level ${ }^{*} p<0.05$.

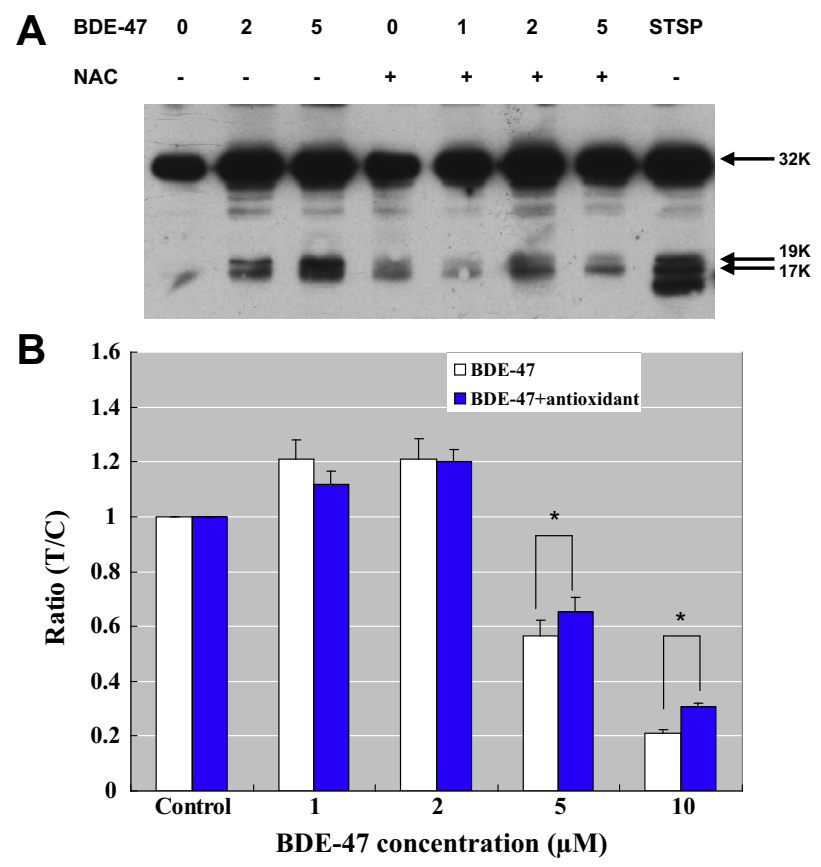

Fig. 4. (A) Western blot analysis of the effect of NAC pretreatment (antioxidant) on BDE-47-induced activation and proteolytic cleavage of Caspase- 3 in macrophages. Cells were exposed to BDE-47, with or without NAC pretreatment, and cell lysates were run on $15 \%$ SDS-PAGE. The proteins were transferred to a polyvinylidene difluoride membrane and immunoblotted using anti-Caspase- 3 antibody; (B) Macrophage cell viability upon BDE-47 exposure with or without NAC pretreatment, as measured by WST-1 assay; Asterisk indicates significant difference from each other at level ${ }^{*} p<0.05$. 

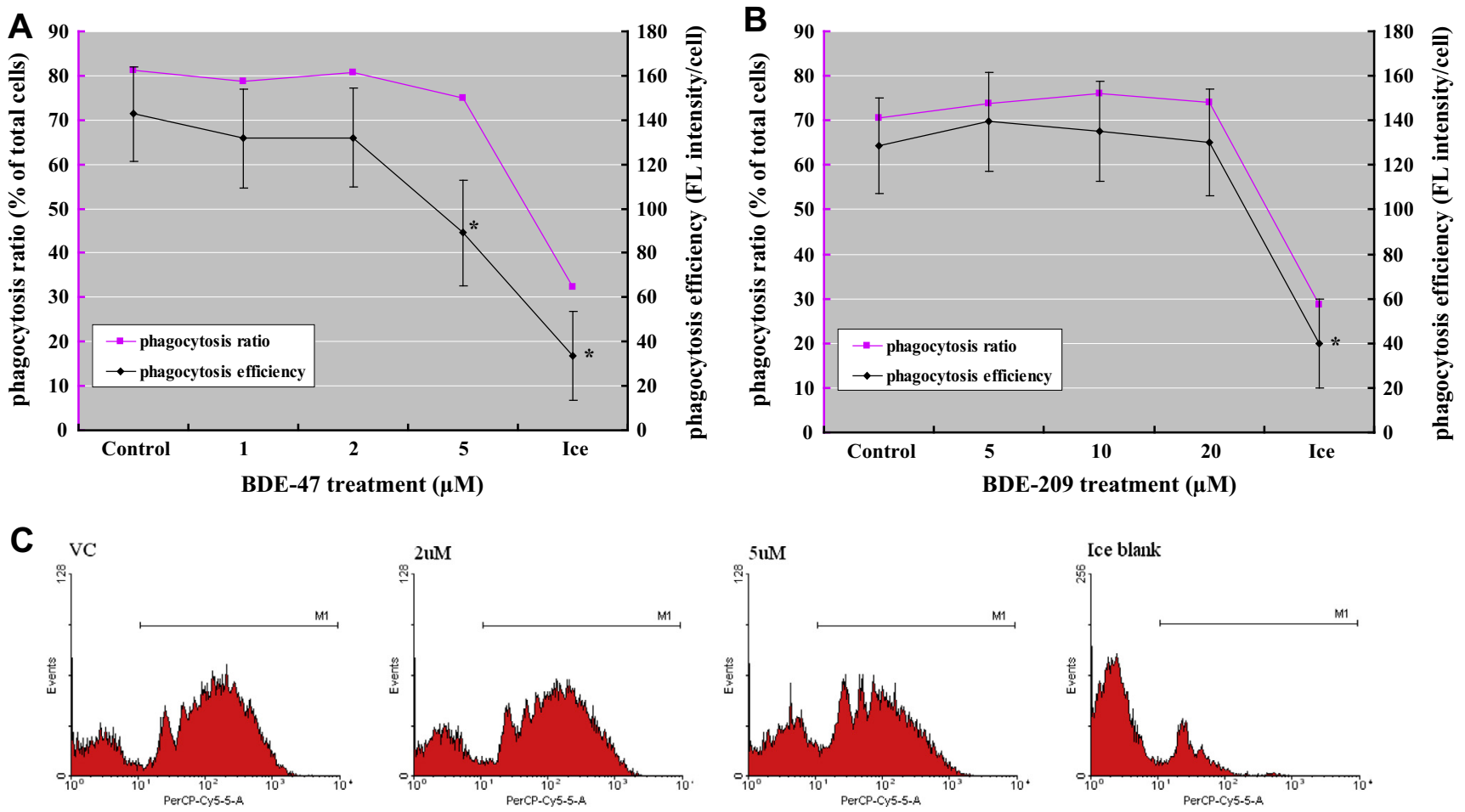

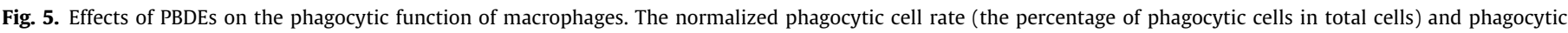

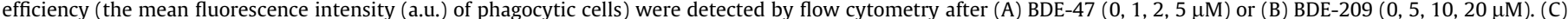

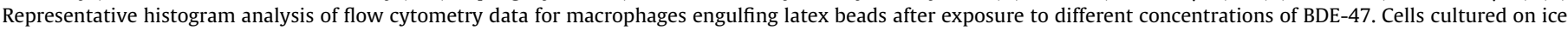

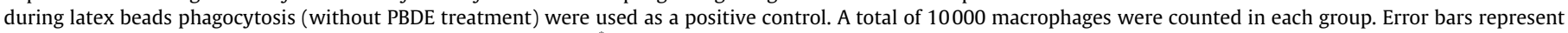
SD. Asterisk indicates significant difference from control at level ${ }^{*} p<0.05$.

BDE-209, 20 and $50 \mu \mathrm{M}$ ) exposure scenarios. The concentrations were also based on our cell viability analysis and comparable to those used in previous studies (Frouin et al., 2010; Jin et al., 2010).

Following exposure to PBDEs, both flow cytometric and immunochemical blotting analyses showed a concentration- and timedependent increase in cell apoptosis and necrosis in PBDE-exposed macrophages. Compared with other cells, macrophages are equally sensitive to BDE-209 but more susceptible to BDE-47 toxicity. For example, RTG-2, a fish cell line, was significantly affected by $12.5 \mu \mathrm{M}$ BDE-47 and $25 \mu \mathrm{M}$ BDE-209 (Jin et al., 2010). In Jurkat T cells and granulocytes, BDE-47 induced cell apoptosis at concentrations of $25 \mu \mathrm{M}$ and $12 \mu \mathrm{M}$, respectively (Frouin et al., 2010; Jin et al., 2010). In neuron cells, including primary rat hippocampal neuron and SH-SY5Y, BDE-47 was shown to cause cell apoptosis and DNA damage at $41.2 \mu \mathrm{M}$ (He et al., 2008; He, 2008). In addition, both Jin's study and this study revealed that BDE-47 is more toxic than BDE-209, which is in accordance with the observation that lower brominated congeners are more toxic than BDE-209 (Darnerud et al., 2001; Shaw et al., 2009), most likely due to its higher bioaccumulative property and lower hydrophobicity.

The immune system is a network of cells, tissues, and organs that work together to protect the body from harmful substances or microorganisms. Subtle changes in some of the components of the immune system may occur before major changes/acute toxicity or death (Fournier et al., 2000). Once the toxicity of PBDEs to immune cells was determined, our focus was directed towards how PBDEs affect the function of immune cells. Although phagocytosis is an important function of macrophages for protecting cells from foreign material invasion, this study showed no effect of PBDEs on this function at non-cytotoxic concentrations. However, the antigen presenting ability, or the ability to provide the co-stimulatory signals for the activation of lymphocytes (Burke and Lewis, 2002; Servet-Delprat et al., 2002), was inhibited by non-cytotoxic
PBDEs in a concentration-dependent manner, which led to significant suppression of T-cell proliferation. These results suggested a dysfunction of macrophages upon non-cytotoxic PBDE exposure, which might explain the suppression effects on immune functions, including lymphocyte proliferation and antibody production, in BDE-209 exposed rats (Liu et al., 2012) because lymphocyte proliferation and maturation are highly dependent on accessory cell functions. The same inhibition effects were also evident in female mice exposed to DE-71 (Fair et al., 2012). The biased lymphoproliferation resulted from PBDE exposure were usually associated with pro-inflammatory cytokine expression and release (Beineke et al., 2005; Hennigar et al., 2012), modulating immune responses. The observations on macrophage functions are of great biological significance in that PBDEs were able to rapidly perturb the interaction between macrophages and $\mathrm{T}$ cells, and thus, the accessory cell function of macrophages, without causing direct cell death/organ damage. The results also highlighted the necessity of evaluating cell functions during the risk assessment of PBDE immunotoxicity.

Reactive oxygen species (ROS) are formed as a metabolic byproduct of electron transfer to molecular oxygen, which is found to be associated with mitochondrial function and respiration (Vernon and Tang, 2013). The balance between intracellular ROS production and antioxidant production systems plays an important role in maintaining eukaryotic homeostasis and is closely associated with the intrinsic apoptotic pathway (Finkel, 2003). In an effort to elucidate the toxic mechanism(s) of PBDEs in macrophages, we investigated the role of PBDEs in modulating the balance between intracellular ROS and glutathione. The data showed that the reduction of GSH occurred in parallel with the over-production of ROS, in response to BDE-47 and BDE-209 exposure. In vitro, at various concentrations, PBDE-induced oxidative stress was also commonly found in many cell lines, including gonadal cells and germ cells (Jin et al., 2010), neurons (Pellacani et al., 

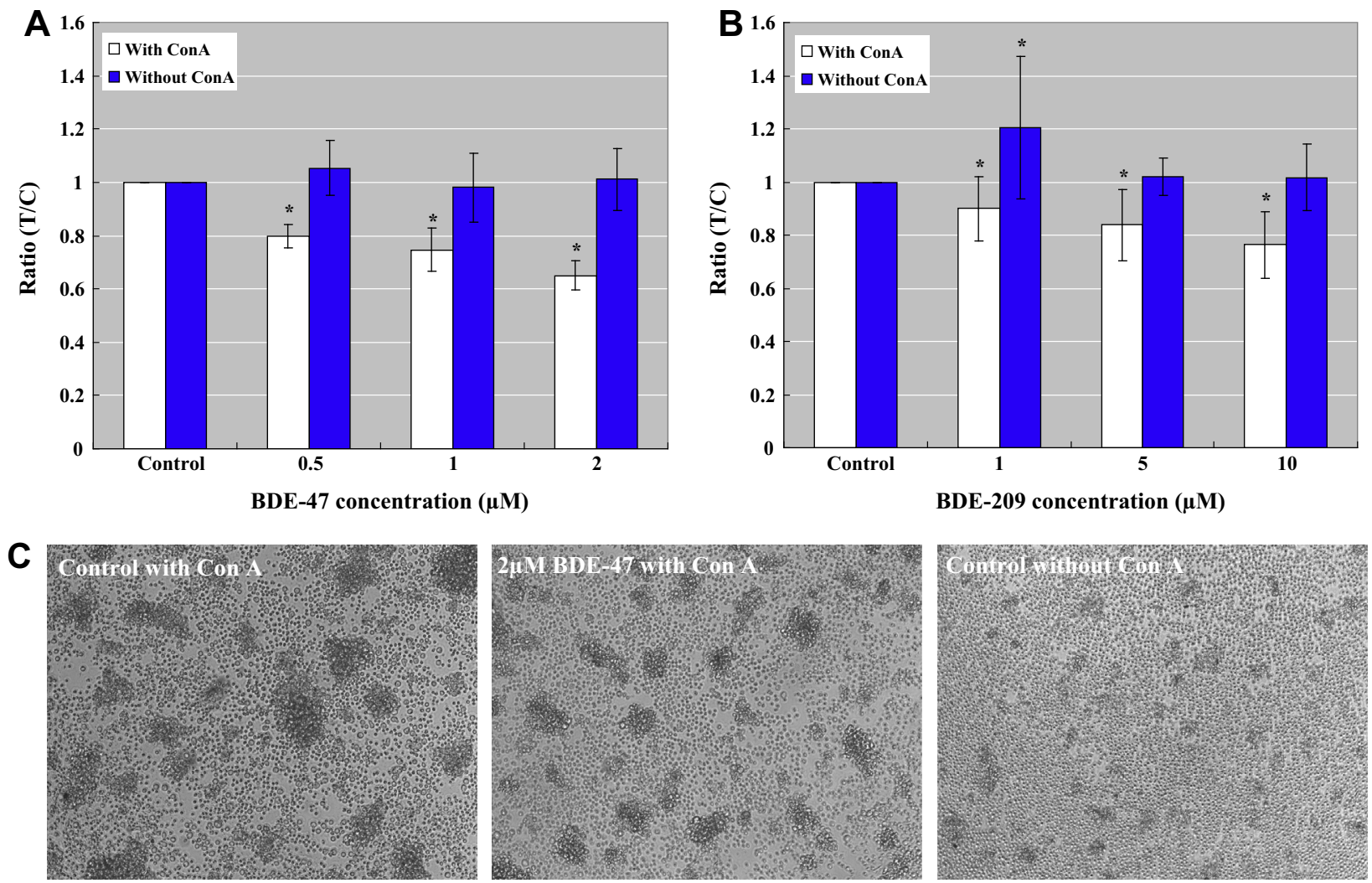

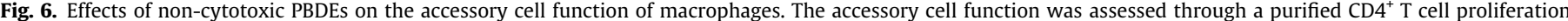

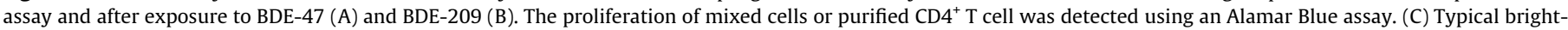

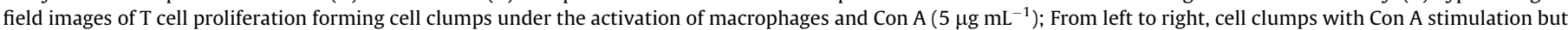

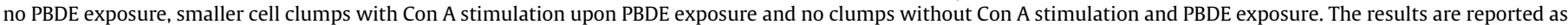

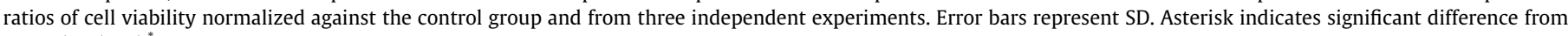
control at level ${ }^{*} p<0.05$.

2012), liver cells (Zhong et al., 2011), and immune cells (Yan et al., 2011), causing global gene disturbance and DNA damage. In vivo, oxidative stress was previously demonstrated as a mechanism of PBDE toxicity in earthworms (Eisenia fetida) (Xie et al., 2011) and CD-1 mice (Tseng et al., 2013). The likely mechanism might be related to the activation of tyrosine kinases, which is followed by PI3-kinase, PKC and PLC activation, resulting in increased intracellular calcium concentrations (Reistad and Mariussen, 2005). Alternatively, ROS signaling, particularly through NF- $\kappa B$, might play a critical role in the transcription and translation of NF- $\kappa B$ target genes, including various cytokines and chemokines that recruit and stimulate macrophages (Forman and Torres, 2002; Vernon and Tang, 2013). By this mechanism, PBDE-induced ROS overproduction modulates cellular physiology of phagocytic cells (Babior, 2000) and therefore disrupts macrophage functions (Dalton et al., 2002), which might explain the inhibitory effects PBDEs have on the accessory cell function of macrophages.

$\mathrm{N}$-acetyl-L-cysteine (NAC) can protect cells against oxidative stress by increasing the cytoplasmic reserve of glutathione and modulating redox-sensitive cellular transduction components and transcriptional factors (Han et al., 2007; Sadowska et al., 2007). To confirm that ROS induction is indeed the mechanism for PBDE cytotoxicity, we pretreated macrophages with NAC and then exposed the cells to PBDEs. The results indicated that NAC pretreatment partially attenuated cell death (Fig. 4B), indicating that there might be other apoptotic pathways involved in PBDE immunotoxicity. In general, there are two main apoptotic pathways: the extrinsic or death receptor pathway and the intrinsic or mitochondrial pathway, each with their characteristic gene-regulated signaling (Elmore, 2007). Caspase-3 is the most important of the executioner Caspases and is activated by any of the initiator Caspases including Caspase-8 (extrinsic pathway) and Caspase-9 (intrinsic pathway). The extrinsic signaling pathway involves death receptors including TNF-alpha/TNFR1, FasL/FasR etc., whereas the intrinsic signaling pathway involves non-receptor-mediated stimuli that target mitochondrial-initiated events, including production of ROS. Therefore, we measured the expression of genes related to both pathways, including Caspase-3,-8,-9, Bax, and TNFR1. The results showed the activation of all genes, indicating the involvement of both pathways in PBDE-induced cell death. This phenomenon should not be taken as an exception because it has been shown that the two pathways are linked and that the molecules in one pathway can influence the other (Igney and Krammer, 2002). Simultaneously, the data also warranted study of the interactions between death receptors and PBDEs for a better understanding of the mechanisms of PBDE toxicity.

In summary, this study investigated the effects of BDE-209 and BDE-47 on cell viability, immune functions and apoptotic pathways in primary murine peritoneal macrophages. The results indicated that both PBDE congeners reduced cell viability through apoptosis and necrosis, and BDE-47 is more potent than BDE-209. At noncytotoxic concentrations, BDE-47 and BDE-209 did not influence macrophage phagocytic function, but they exerted severe effects on accessory cell function. PBDEs induced ROS over-production and depleted GSH in macrophages. However, NAC pretreatment could only partially attenuate the cytotoxicity, indicating only a partial role of ROS in PBDE-induced toxicity. Further measurements on the expression of apoptosis-related genes confirmed that both 
intrinsic and extrinsic pathways were involved in PBDE-induced toxicity in macrophages. The functional analyses performed in this study revealed the immune modulation activity of PBDEs, especially accessory cell function, at non-cytotoxic levels. The data obtained in this study might shed light on a better understanding on the immunotoxicity of PBDEs.

\section{Acknowledgments}

This work was supported by the National Basic Research Program of China (No. 2011CB936001), and the National Natural Science Foundation of China (21277158, 21177138, 21377142).

\section{Appendix A. Supplementary material}

Supplementary data associated with this article can be found, in the online version, at http://dx.doi.org/10.1016/j.chemosphere. 2014.08.029.

\section{References}

Arkoosh, M.R., Boylen, D., Dietrich, J., Anulacion, B.F., Ginaylitalo, Bravo, C.F. Johnson, L.L., Bravo, F.J., Collier, T.K., 2010. Disease susceptibility of salmon exposed to polybrominated diphenyl ethers (PBDEs). Aquat. Toxicol. 98, 51-59.

Babior, B.M., 2000. Phagocytes and oxidative stress. Am. J. Med. 109, 33-44.

Beineke, A., Siebert, U., McLachlan, M., Bruhn, R., Thron, K., Failing, K., Müller, G., Baumgärtner, W., 2005. Investigations of the potential influence of environmental contaminants on the thymus and spleen of harbor porpoises (Phocoena phocoena). Environ. Sci. Technol. 39, 3933-3938.

Beineke, A., Siebert, U., Stott, J., Müller, G., Baumgärtner, W., 2007. Phenotypica characterization of changes in thymus and spleen associated with lymphoid depletion in free-ranging harbor porpoises (Phocoena phocoena). Vet. Immunol Immunop. 117, 254-265.

Bondy, G.S., Lefebvre, D.E., Aziz, S., Cherry, W., Coady, L., Maclellan, E., Armstrong, C. Barker, M., Cooke, G., Gaertner, D., Arnold, D.L., Mehta, R., Rowsell, P.R., 2013. Toxicologic and immunologic effects of perinatal exposure to the brominated diphenyl ether (BDE) mixture DE-71 in the Sprague-Dawley rat. Environ. Toxicol. 28, 215-228.

Burke, B., Lewis, C.E., 2002. The Macrophage. Oxford University Press.

Chen, Q., Yu, L., Yang, L., Zhou, B., 2012. Bioconcentration and metabolism of decabromodiphenyl ether (BDE-209) result in thyroid endocrine disruption in zebrafish larvae. Aquat. Toxicol. 110-111, 141-148.

Dalton, T.P., Puga, A., Shertzer, H.G., 2002. Induction of cellular oxidative stress by aryl hydrocarbon receptor activation. Chem.-Biol. Interact. 141, 77-95.

Darnerud, P.O., Eriksen, G.S., Jóhannesson, T., Larsen, P.B., Viluksela, M., 2001. Polybrominated diphenyl ethers: occurrence, dietary exposure, and toxicology. Environ. Health. Persp. 109, 49-68.

Dingemans, M.M.L., van den Berg, M., Westerink, R.H.S., 2011. Neurotoxicity of PBDEs: Dingemans et al. Respond. Environ. Health Persp. 119, A331-A332.

Dodson, R.E., Perovich, L.J., Covaci, A., Van den Eede, N., Ionas, A.C., Dirtu, A.C., Brody, J.G., Rudel, R.A., 2012. After the PBDE phase-out: a broad suite of flame retardants in repeat house dust samples from California. Environ. Sci. Technol. $46,13056-13066$.

Elmore, S., 2007. Apoptosis: a review of programmed cell death. Toxicol. Pathol. 35 495-516.

Fair, P.A., Stavros, H.-C., Mollenhauer, M.A.M., DeWitt, J.C., Henry, N., Kannan, K, Yun, S.H., Bossart, G.D., Keil, D.E., Peden-Adams, M.M., 2012. Immune function in female B6C3F1 mice is modulated by DE-71, a commercial polybrominated diphenyl ether mixture. J. Immunotoxicol. 9, 96-107.

Finkel, T., 2003. Oxidant signals and oxidative stress. Curr. Opin. Cell Biol. 15, 247-254.

Forman, H.J., Torres, M., 2002. Reactive oxygen species and cell signaling: respiratory burst in macrophage signaling. Am. J. Respir. Crit. Care Med. 166 S4-8.

Fournier, M., Cyr, D., Blakley, B., Boermans, H., Brousseau, P., 2000. Phagocytosis as a biomarker of immunotoxicity in wildlife species exposed to environmental xenobiotics. Am. Zool. 40, 412-420.

Frouin, H. Lebeuf, M. Hammill, M. Masson, S, Fournier, M., 2010, Effects of individual polybrominated diphenyl ether (PBDE) congeners on harbour sea immune cells in vitro. Mar. Pollut. Bull. 60, 291-298.

Han, Y.W., Kim, S.Z., Kim, S.H., Park, W.H., 2007. The changes of intracellular $\mathrm{H}_{2} \mathrm{O}_{2}$ are an important factor maintaining mitochondria membrane potential of antimycin A-treated As4.1 juxtaglomerular cells. Biochem. Pharmacol. 73, $863-872$.

He, W., 2008. Effects of PBDE-47 on cytotoxicity and genotoxicity in human neuroblastoma cells in vitro. Mutat. Res.-Gen. Toxicol. Environ. 649, 62-70.

He, P., He, W., Wang, A., Xia, T., Xu, B., Zhang, M., Chen, X., 2008. PBDE-47-induced oxidative stress, DNA damage and apoptosis in primary cultured rat hippocampal neurons. Neurotoxicology 29, 124-129.
Hennigar, S.R., Myers, J.L., Tagliaferro, A.R., 2012. Exposure of alveolar macrophages to polybrominated diphenyl ethers suppresses the release of pro-inflammatory products in vitro. Exp. Biol. Med. (Maywood) 237, 429-434.

Hites, R.A., 2004. Polybrominated diphenyl ethers in the environment and in people: a meta-analysis of concentrations. Environ. Sci. Technol. 38, 945956.

Igney, F.H., Krammer, P.H., 2002. Death and anti-death: tumour resistance to apoptosis. Nat Rev Cancer 2, 277-288.

Jin, S., Yang, F., Hui, Y., Xu, Y., Lu, Y., Liu, J., 2010. Cytotoxicity and apoptosis induction on RTG-2 cells of $2,2^{\prime}, 4,4^{\prime}$-tetrabromodiphenyl ether (BDE-47) and decabrominated diphenyl ether (BDE-209). Toxicol. In Vitro 24, $1190-1196$.

Kim, T.H., Bang du, Y., Lim, H.J., Jin Won, A., Ahn, M.Y., Patra, N., Chung, K.K., Kwack, S.J., Park, K.L., Han, S.Y., Choi, W.S., Han, J.Y., Lee, B.M., Oh, J.E., Yoon, J.H., Lee, J., Kim, H.S., 2012. Comparisons of polybrominated diphenyl ethers levels in paired South Korean cord blood, maternal blood, and breast milk samples. Chemosphere 87, 97-104.

Krocova, Z., Macela, A., Kroca, M., Hernychova, L., 2000. The immunomodulatory effect(s) of lead and cadmium on the cells of immune system in vitro. Toxicol. In Vitro 14, 33-40.

Li, M., Carpio, D.F., Zheng, Y., Bruzzo, P., Singh, V., Ouaaz, F., Medzhitov, R.M., Beg, A.A. 2001. An essential role of the NF- $\kappa B / T o l l-l i k e$ receptor pathway in induction of inflammatory and tissue-repair gene expression by necrotic cells. J. Immunol. 166, 7128-7135.

Li, Z.-H., Liu, X.-Y., Wang, N., Chen, J.-S., Chen, Y.-H., Huang, J.-T., Su, C.-H., Xie, F., Yu, B., Chen, D.-J., 2012. Effects of decabrominated diphenyl ether (PBDE-209) in regulation of growth and apoptosis of breast, ovarian, and cervical cancer cells. Environ. Health Perspect. 120, 541-546.

Li, X., Gao, Y., Guo, L.-H., Jiang, G., 2013. Structure-dependent activities of hydroxylated polybrominated diphenyl ethers on human estrogen receptor. Toxicology 309, 15-22.

Liu, X., Zhan, H., Zeng, X., Zhang, C., Chen, D., 2012. The PBDE-209 exposure during pregnancy and lactation impairs immune function in rats. Mediators Inflamm. 2012. http://dx.doi.org/10.1155/2012/692467.

Ni, K., Lu, Y., Wang, T., Kannan, K., Gosens, J., Xu, L., Li, Q., Wang, L., Liu, S., 2013. A review of human exposure to polybrominated diphenyl ethers (PBDEs) in China. Int. J. Hyg. Environ. Health 216, 607-623.

Pallardy, M., Biola, A., Lebrec, H., Bréard, J., 1999. Assessment of apoptosis in xenobiotic-induced immunotoxicity. Methods 19, 36-47.

Pellacani, C., Buschini, A., Galati, S., Mussi, F., Franzoni, S., Costa, L.G., 2012. Evaluation of DNA damage induced by 2 polybrominated diphenyl ether flame retardants (BDE-47 and BDE-209) in SK-N-MC cells. Int. J. Toxicol. 31, $372-$ 379.

Pfaffl, M.W., Horgan, G.W., Dempfle, L., 2002. Relative expression software tool (REST®) for group-wise comparison and statistical analysis of relative expression results in real-time PCR. Nucleic Acids Res. 30, e36.

Reistad, T., Mariussen, E., 2005. A commercial mixture of the brominated flame retardant pentabrominated diphenyl ether (DE-71) induces respiratory burst in human neutrophil granulocytes in vitro. Toxicol. Sci. 87, 57-65.

Ren, X.M., Guo, L.-H., 2012. Assessment of the binding of hydroxylated polybrominated diphenyl ethers to thyroid hormone transport proteins using a site-specific fluorescence probe. Environ. Sci. Technol. 46, 4633-4640.

Ren, X.M., Guo, L.H., 2013. Molecular toxicology of polybrominated diphenyl ethers: nuclear hormone receptor mediated pathways. Environ. Sci. Process. Impacts 15, 702-708.

Rodenburg, R., Raats, J., Pruijn, G., Van Venrooij, W., 2000. Cell death: a trigger of autoimmunity? BioEssays 22, 627-636.

Rose, M., Bennett, D.H., Bergman, Å., Fängström, B., Pessah, I.N., Hertz-Picciotto, I., 2010. PBDEs in 2-5 year-old children from California and associations with diet and indoor environment. Environ. Sci. Technol. 44, 2648-2653.

Sadowska, A.M., Manuel-y-Keenoy, B., De Backer, W.A., 2007. Antioxidant and antiinflammatory efficacy of NAC in the treatment of COPD: discordant in vitro and in vivo dose-effects: a review. Pulm. Pharmacol. Ther. 20, 9-22.

Servet-Delprat, C., Arnaud, S., Jurdic, P., Nataf, S., Grasset, M.F., Soulas, C., Domenget, C., Destaing, O., Rivollier, A., Perret, M., Dumontel, C., Hanau, D., Gilmore, G.L. Belin, M.F., Rabourdin-Combe, C., Mouchiroud, G., 2002. Flt $3^{+}$macrophage precursors commit sequentially to osteoclasts, dendritic cells and microglia. BMC Immunol. 3, 15. http://dx.doi.org/10.1186/1471-2172-1183-1115.

Shaw, S.D., Berger, M.L., Brenner, D., Kannan, K., Lohmann, N., Päpke, O., 2009. Bioaccumulation of polybrominated diphenyl ethers and hexabromocyclododecane in the northwest Atlantic marine food web. Sci. Total Environ. 407, 3323-3329.

Stapleton, H.M., Klosterhaus, S., Keller, A., Ferguson, P.L., van Bergen, S., Cooper, E. Webster, T.F., Blum, A., 2011. Identification of flame retardants in polyurethane foam collected from baby products. Environ. Sci. Technol. 45, 5323-5331.

Tseng, L.-H., Hsu, P.-C., Lee, C.-W., Tsai, S.-S., Pan, M.-H., Li, M.-H., 2013. Developmental exposure to decabrominated diphenyl ether (BDE-209): effects on sperm oxidative stress and chromatin DNA damage in mouse offspring. Environ. Toxicol. 28, 380-389.

Vernon, P.J., Tang, D., 2013. Eat-me: autophagy, phagocytosis, and reactive oxygen species signaling. Antioxid. Redox Signal. 18, 677-691.

Wan, B., Fleming, J.T., Schultz, T.W., Sayler, G.S., 2006. In vitro immune toxicity of depleted uranium: effects on murine macrophages, CD4 ${ }^{+}$T-cells and gene expression profiles. Environ. Health Persp. 114, 85-91.

Wang, Y., Luo, C., Li, J., Yin, H., Li, X., Zhang, G., 2011. Characterization of PBDEs in soils and vegetations near an e-waste recycling site in South China. Environ. Pollut. 159, 2443-2448. 
Xie, X., Wu, Y., Zhu, M., Zhang, Y.K., Wang, X., 2011. Hydroxyl radical generation and oxidative stress in earthworms (Eisenia fetida) exposed to decabromodiphenyl ether (BDE-209). Ecotoxicology 20, 993-999.

Yan, C., Huang, D., Zhang, Y., 2011. The involvement of ROS overproduction and mitochondrial dysfunction in PBDE-47-induced apoptosis on Jurkat cells. Exp. Toxicol. Pathol. 63, 413-417.

Ye, R.R., Lei, E.N., Lam, M.H., Chan, A.K., Bo, J., van de Merwe, J.P., Fong, A.C., Yang, M.M., Lee, J.S., Segner, H.E., Wong, C.K., Wu, R.S., Au, D.W., 2011. Gender-specific modulation of immune system complement gene expression in marine medaka
Oryzias melastigma following dietary exposure of BDE-47. Environ. Sci. Pollut. Res. Int. 19, 2477-2487.

Zhang, J.G., Sun, X.W., Ai, H., 2012. Levels and congener profiles of polybrominated diphenyl ethers (PBDEs) in primipara breast milk from Shenzhen and exposure risk for breast-fed infants. J. Environ. Monit. 14, 893-900.

Zhong, Y.F., Wang, L.L., Yin, L.L., An, J., Hou, M.L., Zheng, K.W., Zhang, X.Y., Wu, M.H., Yu, Z.Q., Sheng, G.Y., Fu, J.M., 2011. Cytotoxic effects and oxidative stress response of six PBDE metabolites on human L02 cells. J. Environ. Sci. Health. A Tox. Hazard Subst. Environ. Eng. 46, 1320-1327. 